\title{
Apparent and true digestibility of protein and amino acid in feedstuffs used in Nile Tilapia feed as determined by the technique of dissection ${ }^{1}$
}

\author{
Felipe Barbosa Ribeiro², Eduardo Arruda Teixeira Lanna ${ }^{2}$, Marcos Antonio Delmondes \\ Bomfim² $^{2}$, Juarez Lopes Donzele ${ }^{2}$, Moisés Quadros², Patrícia de Souza Lima Cunha ${ }^{2}$, \\ Sylvia Sanae Takishita ${ }^{2}$, Rafael Alves Vianna ${ }^{2}$
}

\footnotetext{
1 Financiado por Ajinomoto Biolatina Indústria e Comércio Ltda.

2 Departamento de Zootecnia - UFV.
}

\begin{abstract}
The objective of this study was to determine the coefficients of apparent and true digestibility of protein and amino acids of five feedstuffs (corn, wheat bran, soybean meal, corn gluten meal and fish meal) in 900 sex-reversed Nile tilapia (Oreochromis niloticus) of the Thai strain during the growth phase, with an initial weight of $315 \pm 8.45 \mathrm{~g}$. A total of 750 fish were distributed according to a randomized block design (repetitions in time) into five treatments with six replicates of 25 fish each. The remaining 150 fish were fed a protein-free diet to measure endogenous protein and amino acid losses in order to determine the true digestibility of these components. Each tested diet contained a single protein source, which consisted of one of the evaluated feedstuffs. Digestibility was indirectly estimated using chromic oxide at $0.50 \%$ as marker. Digesta was collected from the last $5 \mathrm{~cm}$ of the distal intestine (between the ileal-rectal valve and the anus) using the dissection technique. Apparent digestibility coefficients of protein and amino acids were, on average, 74.69 and $73.62 \%$ for corn, 73.74 and $72.81 \%$ for wheat bran, 86.01 and $84.66 \%$ for soybean meal, 85.19 and $84.29 \%$ for corn gluten meal, 76.74 and $75.56 \%$ for fish meal, respectively. True digestibility coefficients of protein and amino acids were, on average, 85.21 and $83.97 \%$ for corn, 84.41 and $83.74 \%$ for wheat bran, 87.22 and $87.51 \%$ for soybean meal, 87.97 and $87.34 \%$ for corn gluten meal, and finally 79.58 and $78.44 \%$ for fish meal, respectively.
\end{abstract}

Key Words: digestible amino acids, endogenous loss, protein-free diet, Oreochromis niloticus

\section{Introduction}

One of the biggest challenges of fish production is to obtain high productivity with the lowest possible waste discharge in the environment. This particularly applies to nitrogen and phosphorus excretion in intensive fish production systems that depend exclusively on balanced feeds (Sugiura et al., 2001; Furuya et al., 2005; Lanna et al., 2005).

The evaluation of the digestibility coefficients of feedstuffs is an important tool to determine the nutritional values to be applied in the formulation of nutritionallycomplex fish feeds. The determination of digestibility coefficients is usually based on fecal measurements, and essentially depends on the conditions and methods applied in digestibility trials (Portz, 2001).

Some researchers have tried to determine which methodology of nutritional evaluation best represents the feedstuffs inside the digestive tract of fish, and which is also convenient, fast, cheap, and that can be routinely used. However, despite these efforts, a standardized method to evaluate protein and amino acid digestibility in fish is not yet available (Vandenberg \& De La Noue 2001; Abimorad \& Carneiro, 2004).

Among fecal collection techniques, settlement collection is the most commonly used (Cho et al.,1982), but feces fragmentation and leaching of fecal components may result in an overestimation of digestibility values (Glencross et al., 2007). The techniques that prevent any nutrient leaching require removing the fish from the water and collecting fecal samples directly from the distal intestinal region, such as the dissection technique (Austreng, 1978; Windell et al., 1978; Henken et al., 1985).

The objective of the present study was to determine apparent and true digestibility coefficients of protein and amino acids in some feedstuffs used in Nile tilapia feeds, using the dissection technique for fecal collection.

\section{Material and Methods}

A total of 900 sex-reversed Nile tilapia (Oreochromis niloticus) of the Thai strain, with $315 \pm 8.45 \mathrm{~g}$ initial weight, was used. Out of the total 900 fish, 750 were distributed according to a randomized block (repetition in time) 
experimental design into five treatments with six replicates of 25 fish each. The remaining 150 fish were fed a proteinfree diet in order to determine endogenous protein losses, which were used in the calculation of the true digestibility coefficients of protein and amino acids. The treatments consisted of five test diets, each one including a single protein source (corn, wheat bran, soybean meal, corn gluten meal $(60 \% \mathrm{CP})$, or fish meal).

Diets were formulated to contain $32 \%$ crude protein to evaluate protein feedstuffs (soybean meal, fish meal and corn gluten) and 6.5\% crude protein to evaluate energy feedstuffs (corn and wheat bran) (Table 1). Crude fiber, calcium and phosphorus (except for fish meal), vitamin and mineral levels were similar in all experimental diets. Cellulose was added to achieve $3.90 \%$ crude fiber in all diets. In addition, diets contained $0.50 \%$ chromic oxide $\left(\mathrm{Cr}_{2} \mathrm{O}_{3}\right)$, which was used as a marker for digestibility determination (Table 2).

The fish meal used in the present experiment was locally produced, and contained 53.39\% crude protein, 25.42\% ashes, $6.89 \%$ calcium and $4.16 \%$ available phosphorus on an as-fed basis.

Fish were maintained in six polyethylene tanks, with 300-L capacity each, and equipped with individual aeration systems, water supply, and bottom outflow in a minimal water recirculation and renewal system of $25.0 \%$ per day.

Water was supplied to the tanks from the water treatment system of Universidade Federal de Viçosa (UFV), and was previously dechlorinated and warmed using electrical resistances at a temperature controlled by a thermostat.
Tank water was daily measured at 07:30 and 17:30 hours with the aid of a 0 to $50^{\circ} \mathrm{C}$ mercury-in-glass thermometer. Water $\mathrm{pH}$ and dissolved oxygen were monitored every seven days using a potentiometer and an oximeter, respectively.

A photoperiod of 12 hours of light was applied using mixed lamp bulbs controlled by an automatic timer.

Animals were fed pelleted diets. Before the experimental period, increasing amounts of the experimental diets were supplied during three days until regular intake was obtained.

The duration of the digestibility trial was nine days, with three days for adaptation, five days for supply of the experimental diets, and one day for digesta collection.

The experimental diets were supplied at $2 \%$ live weight to all treatment groups four times daily, at 09:00, 12:00, 15:00, and 18:00 h, divided in equal amounts.

On day 5, fish were placed in a bucket with ice for stunning, and sacrificed. Fish were laterally opened to remove the content of the distal intestinal segment at $5 \mathrm{~cm}$ from the anus (between the ileal-rectal valve and the anus) and placed on a petri dish. Using surgical scissors, the intestine was longitudinally opened and the content was removed with a spatula and placed in a different petri dish. The digesta of each experimental unit, consisting of 25 fish, was pooled into a single sample. All the collected material was frozen at $-70^{\circ} \mathrm{C}$ and then freeze-dried for 72 hours in order to prevent amino acid break down.

The analyses of dry matter and crude protein content of the experimental diets and of the digesta, as well as

Table 1 - Chemical composition of feedstuffs ${ }^{1}$

\begin{tabular}{|c|c|c|c|c|c|}
\hline Amino acid & Corn & Wheat bran & Soybean meal & Corn gluten & Fish meal \\
\hline \multicolumn{6}{|l|}{ Essential } \\
\hline Arginine & 0.32 & 1.00 & 3.07 & 1.93 & 2.99 \\
\hline Histidine & 0.21 & 0.44 & 1.05 & 1.18 & 1.12 \\
\hline Isoleucine & 0.23 & 0.45 & 1.89 & 2.48 & 1.91 \\
\hline Leucine & 0.81 & 0.86 & 3.16 & 10.6 & 3.27 \\
\hline Lysine & 0.20 & 0.61 & 2.66 & 0.97 & 3.48 \\
\hline Methionine & 0.14 & 0.24 & 0.55 & 1.41 & 1.42 \\
\hline Phenylalanine & 0.33 & 0.59 & 2.12 & 3.89 & 1.97 \\
\hline Threonine & 0.26 & 0.49 & 1.68 & 2.00 & 1.98 \\
\hline Valine & 0.32 & 0.66 & 1.96 & 2.77 & 2.42 \\
\hline \multicolumn{6}{|l|}{ Non-essential } \\
\hline Aspartic acid & 0.45 & 1.04 & 4.86 & 3.73 & 4.36 \\
\hline Glutamic acid & 1.23 & 2.60 & 7.64 & 13.47 & 5.76 \\
\hline Alanine & 0.49 & 0.68 & 1.82 & 5.55 & 3.16 \\
\hline Cystine & 0.15 & 0.30 & 0.55 & 1.04 & 0.39 \\
\hline Glycine & 0.26 & 0.79 & 1.78 & 1.58 & 4.2 \\
\hline Serine & 0.33 & 0.65 & 2.21 & 3.29 & 1.98 \\
\hline Tyrosine & 0.25 & 0.46 & 1.53 & 3.2 & 1.53 \\
\hline Dry matter & 88.68 & 88.19 & 91.01 & 92.48 & 91.71 \\
\hline Crude protein & 7.33 & 15.88 & 46.89 & 63.92 & 53.39 \\
\hline
\end{tabular}

\footnotetext{
${ }^{1}$ Values expressed as a percentage of fresh matter.
} 
Table 2 - Ingredient composition of the experimental diets

\begin{tabular}{|c|c|c|c|c|c|c|}
\hline \multirow[t]{2}{*}{ Ingredients } & \multicolumn{6}{|c|}{ Diets } \\
\hline & Protein-free diet & Corn & Wheat bran & Soybean meal & Corn gluten & Fish meal \\
\hline Corn & - & 78.00 & - & - & - & - \\
\hline Wheat bran & - & - & 39.50 & - & - & - \\
\hline Soybean meal & - & - & - & 70.60 & - & - \\
\hline Corn gluten 60 & - & - & - & - & 52.74 & - \\
\hline Fish meal & - & - & - & - & - & 58.63 \\
\hline Corn starch & 82.53 & 6.80 & 49.33 & 18.48 & 30.94 & 28.00 \\
\hline Soybean oil & 6.20 & 6.20 & 6.20 & 6.20 & 6.20 & 6.20 \\
\hline Cellulose ${ }^{1}$ & 5.60 & 3.73 & 0.25 & 0.15 & 4.85 & 5.60 \\
\hline Calcitic limestone & 0.10 & 0.70 & 1.15 & 1.00 & 0.90 & 0.00 \\
\hline Dicalcium phosphate & 4.00 & 3.00 & 2.00 & 2.00 & 2.80 & 0.00 \\
\hline Vitamin and mineral supplement ${ }^{2}$ & 0.50 & 0.50 & 0.50 & 0.50 & 0.50 & 0.50 \\
\hline Vitamin $\mathrm{C}^{3}$ & 0.05 & 0.05 & 0.05 & 0.05 & 0.05 & 0.05 \\
\hline Sal & 0.50 & 0.50 & 0.50 & 0.50 & 0.50 & 0.50 \\
\hline Antioxidant (BHT) & 0.02 & 0.02 & 0.02 & 0.02 & 0.02 & 0.02 \\
\hline Chromic oxide & 0.50 & 0.50 & 0.50 & 0.50 & 0.50 & 0.50 \\
\hline Total & 100 & 100 & 100 & 100 & 100 & 100 \\
\hline \multicolumn{7}{|l|}{ Calculated composition } \\
\hline Crude protein $(\%)^{4}$ & 0.00 & 6.50 & 6.50 & 32.00 & 32.00 & 32.00 \\
\hline Dig. energy $(\mathrm{kcal} / \mathrm{kg})^{5}$ & 2716 & 3058 & 2911 & 3076 & 3245 & 3125 \\
\hline Crude fiber (\%) & 3.90 & 3.90 & 3.90 & 3.90 & 3.90 & 3.90 \\
\hline Total calcium (\%) & 1.00 & 1.00 & 1.00 & 1.00 & 1.00 & 4.04 \\
\hline Available phosphorus (\%) & 0.55 & 0.50 & 0.39 & 0.45 & 0.49 & 2.44 \\
\hline Total lysine (\%) & 0.00 & 0.19 & 0.26 & 1.96 & 0.53 & 2.00 \\
\hline
\end{tabular}

chromic oxide concentration in the digesta were conducted at the Animal Nutrition Laboratory of the Department of Animal Science (LNA/DZO) of Universidade Federal de Viçosa (UFV), according to the procedures described by Silva \& Queiroz (2002).

The analyses of the amino acid content of the experimental diets, feedstuffs, and feces were conducted at the laboratory of Ajinomoto Biolatina Ind. and Com. Ltda, using high-performance liquid chromatography (HLPC). Tryptophan and proline contents were not analyzed.

Apparent and true digestibility of protein and amino acids was determined by calculating the indigestibility factor, according to the equations proposed by Rostagno \& Featherston (1977), as follows:

1 - Indigestibility factor (IF):

$\mathrm{IF}=\frac{\mathrm{Cr}_{2} \mathrm{O}_{3} \text { in the diet }}{\mathrm{Cr}_{2} \mathrm{O}_{3} \text { in the digesta }}$

2 - Apparent digestibility coefficient of crude protein (ADCCP):

$\operatorname{ADCCP}(\%)=\frac{\mathrm{CP} \text { diet }-\left(\mathrm{CP} \mathrm{E}_{1} \times \mathrm{IF}_{1}\right)}{\mathrm{CP} \text { diet }} \times 100$

where: $\mathrm{CP}$ = crude protein; $\mathrm{E}_{1}=$ digesta of the evaluated diet and $\mathrm{IF}_{1}=$ indigestibility factor of the tested diet.
Amino acid excretion values obtained from fish fed the protein-free diet were used to determine true digestibility coefficients.

3 - True digestibility coefficient of crude protein (TDCCP):

$\operatorname{TDCCP}(\%)=\frac{\mathrm{CP} \text { diet }-\left(\mathrm{CP} \text { digesta } \times \mathrm{IF}_{1}-\mathrm{eCP} \times \mathrm{IF}_{2}\right)}{\mathrm{CP} \text { diet }} \times 100$ where: $\mathrm{CP}=$ crude protein; $\mathrm{IF}_{1}=$ indigestibility factor of the tested diet; $\mathrm{eCP}=$ endogenous crude protein excreted in the digesta and $\mathrm{IF}_{2}=$ indigestibility factor of the protein-free $\operatorname{diet}(\mathrm{PFD})$.

4 - Apparent digestibility coefficient of amino acids (ADCAA):

$\operatorname{ADCAA}(\%)=\frac{\mathrm{mg} \mathrm{AA} / \mathrm{g} \text { diet }-\mathrm{mg} \mathrm{AA} / \mathrm{g} \mathrm{E}_{1} \times \mathrm{IF}_{1}}{\mathrm{mg} \mathrm{AA} / \mathrm{g} \text { diet }} \times 100$ where: $\mathrm{AA}=$ amino acids; $\mathrm{E}_{1}=$ digesta of the evaluated diet and $\mathrm{IF}_{1}=$ indigestibility factor of the tested diet

5 - True digestibility coefficient of amino acids (TDCAA):

$\operatorname{TDCAA}(\%)=\frac{\mathrm{mgAA} / \mathrm{g} \text { diet }-\left(\mathrm{mgAA} / \mathrm{gE}_{1} \times \mathrm{IF}_{1}-\mathrm{mgAA} / \mathrm{gE}_{2} \times \mathrm{IF}_{2}\right)}{\mathrm{mg} \mathrm{AA} / \mathrm{g} \text { diet }} \times 100$ where: $\mathrm{AA}=$ amino acids; $\mathrm{E}_{1}=$ digesta of the evaluated diet; $\mathrm{E}_{2}=$ digesta of the protein-free diet (PFD); $\mathrm{IF}_{1}=$ 
indigestibility factor of the tested diet and $\mathrm{IF}_{2}=$ indigestibility factor of the protein-free diet (PFD).

\section{Results and Discussion}

The average water temperature during the experimental period was $28.0 \pm 0.39{ }^{\circ} \mathrm{C}$. Average water $\mathrm{pH}$ was $6.6 \pm 0.13$ and average dissolved oxygen, $5.9 \pm 0.54 \mathrm{ppm}$. Water was heated using electrical resistances and water temperature was controlled by a thermostat, which allowed obtaining uniform water temperatures during the entire experimental period. These values are within the range recommended for rearing Nile tilapia, according to Popma \& Phelps (1998).

The apparent digestibility coefficient of crude protein (ADCCP) from corn (74.69\%) was similar to that obtained for wheat bran (73.74\%; Table 3), and consistent with the results of Ribeiro et al. (2011), who observed relative values of 83.57 and $82.87 \%$, respectively, despite obtaining different absolute values. On the other hand, Gonçalves et al. (2009) found ADCCP value of corn was $89.76 \%$, which was lower than that obtained for wheat bran, of 93.54\%.

In corn and wheat bran, average amino acid apparent digestibility coefficients were 73.62 and $72.81 \%$, respectively (Table 3). Among the essential amino acids, leucine presented the highest apparent digestibility coefficient in corn (79.20\%), in agreement with the findings of Wilson et al. (1981) and Furuya et al. (2001). In wheat bran, the amino acid presenting the highest digestibility was arginine
(80.09\%), as also observed by Ribeiro et al. (2011), who obtained a value of $84.97 \%$.

Threonine was the essential amino acid with the lowest apparent digestibility coefficient in corn (70.53\%) and wheat bran (69.70\%), which was also observed by Wilson et al. (1981), Gonçalves et al. (2009) and Ribeiro et al. (2011). This low threonine digestibility may be explained by its high concentration in the mucin layer of the intestinal mucosa (Fuller, 1994) that, along with its low content in corn and wheat bran, would result in lower digestibility values.

In protein feedstuffs, soybean meal ADCCP (86.01\%) was similar to that of corn gluten (85.19\%), whereas fish meal (76.74\%) presented the lowest ADCCP of the feedstuffs of this group (Table 3). Soybean meal ADCCP was lower than those determined by Furuya et al. (2001), of $92.72 \%$; by Pezzato et al. (2002), of 91.56\%; by Boscolo et al. (2002), of 89.28\%; by Gonçalves et al. (2009), of $94.13 \%$; and by Ribeiro et al. (2011), of $91.12 \%$ The apparent digestibility coefficient of crude protein in corn gluten obtained in the present study was also lower than those observed by Pezzato et al. (2002), of 95.96\%; by Meurer et al. (2003), of 97.61\%; by Köprücü \& Özdemir (2005), of $89.00 \%$; by Gonçalves et al. (2009) of 89.32\%; and by Ribeiro et al. (2011), of 90.07\%. However, it must be stressed that in these studies, feces were collected using the settlement method, whereas dissection was used in the present study.

The ADCCP of fish meal was consistent with that obtained by Pezzato et al. (2002), of 78.55\%. However, the

Table 3 - Apparent digestibility coefficients of crude protein and amino acid in the evaluated feedstfuffs as determined by the technique of dissection ${ }^{1}$

\begin{tabular}{|c|c|c|c|c|c|}
\hline Item & Corn & Wheat bran & Soybean meal & Corn gluten & Fish meal \\
\hline Crude protein & 74.69 & 73.74 & 86.01 & 85.19 & 76.74 \\
\hline \multicolumn{6}{|c|}{ Essential amino acids } \\
\hline Arginine & 78.26 & 80.09 & 89.59 & 88.42 & 81.93 \\
\hline Histidine & 72.12 & 72.62 & 85.83 & 80.88 & 80.74 \\
\hline Isoleucine & 73.96 & 73.25 & 83.30 & 82.11 & 72.41 \\
\hline Leucine & 79.20 & 78.25 & 84.17 & 87.98 & 74.08 \\
\hline Lysine & 72.40 & 70.03 & 85.44 & 83.84 & 70.30 \\
\hline Methionine & 71.62 & 72.44 & 84.12 & 83.33 & 75.75 \\
\hline Phenylalanine & 72.64 & 74.52 & 86.52 & 83.86 & 75.88 \\
\hline Threonine & 70.53 & 69.70 & 86.90 & 84.51 & 81.04 \\
\hline Valine & 73.46 & 73.19 & 84.05 & 84.52 & 74.04 \\
\hline \multicolumn{6}{|c|}{ Non-essential amino acids } \\
\hline Aspartic acid & 71.87 & 72.3 & 86.52 & 86.90 & 66.63 \\
\hline Glutamic acid & 71.43 & 69.44 & 84.44 & 91.60 & 76.96 \\
\hline Alanine & 79.39 & 77.75 & 87.28 & 85.59 & 76.42 \\
\hline Cystine & 70.03 & 66.72 & 78.32 & 79.16 & 78.50 \\
\hline Glycine & 76.13 & 73.21 & 77.86 & 77.60 & 74.92 \\
\hline Serine & 74.11 & 70.06 & 83.16 & 84.12 & 73.89 \\
\hline Tyrosine & 70.82 & 71.33 & 87.02 & 84.24 & 75.39 \\
\hline Mean & 73.62 & 72.81 & 84.66 & 84.29 & 75.56 \\
\hline
\end{tabular}

\footnotetext{
${ }^{1}$ Values expressed as percentage, on as-fed basis.
} 
ADCCP of fish meal results reported in the literature can reach values of up to $90.66 \%$ (Meurer et al., 2003) in Nile tilapia. Aksnes et al. (1997) comment that the quality of fish meals available in the market is extremely variable, as it depends on raw material and processing conditions. Analyzing 27 fish meal samples, Romero et al. (1994) obtained 84.5 to $97.0 \%$ protein digestibility for rainbow trout. Brazilian fish meals often present low digestibility coefficients because they are made from processing residues, and may present high ash content and lowquality protein derived from bone protein matrix, skin, scales, and viscera (Boscolo et al., 2004).

Mean apparent digestibility coefficients of amino acids in soybean meal, corn gluten and fish meal were $84.66 \%$, $84.29 \%$ and $75.56 \%$, respectively (Table 3).

In the present study, among the essential amino acids, arginine presented the highest apparent digestibility coefficient (ADC) of all protein feedstuffs tested, with values of $89.59 \%$ for soybean meal, $88.42 \%$ for corn gluten and $81.93 \%$ for fish meal. In most studies found in the literature with Nile tilapia and other fish species, arginine also presented the first or the second highest ADC values among essential amino acids for soybean meal (Wilson et al., 1981; Yamamoto et al., 1998; Furuya et al., 2001; Köprücü \& Özdemir, 2005; Abimorad et al., 2008; Ribeiro et al., 2011), for corn gluten (Yamamoto et al., 1998; Abimorad et al., 2008; Ribeiro et al., 2011) and for fish meal (Wilson et al., 1981; Yamamoto et al., 1998; Furuya et al., 2001; Abimorad et al., 2008; Ribeiro et al., 2011).

Isoleucine, on the other hand, presented the lowest ADC the among essential amino acids for all evaluated protein feedstuffs, with values of $83.30 \%$ for soybean meal, $82.11 \%$ for corn gluten, and $72.41 \%$ for fish meal. Isoleucine was also the essential amino acid with the lowest ADC value obtained by Furuya et al. (2001) for soybean meal; by Yamamoto et al. (1998), Gonçalves et al. (2009) and Ribeiro et al. (2011) for corn gluten; and by Yamamoto et al. (1998) for fish meal. Isoleucine is a hydrophobic amino acid located inside the protein, hindering the hydrolysis of its peptide bonds (Nissen, 1992), which may explain its low digestibility.

The values of endogenous losses of protein and amino acids obtained in the present study (Table 4) were greater than those obtained by Ribeiro et al. (2011) in the same fish species and weight range.

Methionine and cystine presented the lowest endogenous losses, as previously observed by Wilson et al. (1981), with channel catfish; Yamamoto et al. (1998), with common carp; and Ribeiro et al. (2011), with Nile tilapia.
Table 4 - Mean endogenous crude protein and amino acids values as determined using a protein-free diet (PFD) and obtained by the technique of dissection

\begin{tabular}{lc}
\hline Amino acids & PDF intake, $\mathrm{mg} / \mathrm{g}$ \\
\hline Arginine & 0.465 \\
Histidine & 0.351 \\
Isoleucine & 0.444 \\
Leucine & 0.647 \\
Lysine & 0.337 \\
Methionine & 0.265 \\
Phenylalanine & 0.490 \\
Threonine & 0.541 \\
Valine & 0.490 \\
Aspartic acid & 0.712 \\
Glutamic acid & 0.858 \\
Alanine & 0.502 \\
Cystine & 0.234 \\
Glycine & 0.541 \\
Serine & 0.470 \\
Tyrosine & 0.443 \\
Crude protein & 11.01 \\
\hline
\end{tabular}

These results may be partially explained by the lower content of sulfur amino acids both in the mucin layer and in pancreatic secretions compared with other amino acids (Pozza et al., 2003).

There are few reports in the literature on true protein digestibility coefficients for fish, except for the studies of Wilson et al. (1981) with channel catfish (Ictalurus punctatus); Yamamoto et al. (1998), with common carp (Cyprinus carpio), rainbow trout (Oncorhynchus mykiss) and red sea bream (Pagrus major); and Ribeiro et al. (2011), with Nile tilapia.

Crude protein true digestibility coefficients obtained for corn (85.21\%) and wheat bran (84.41\%) (Table 5) were lower than those determined by Ribeiro et al. (2011), of 90.02 and $89.62 \%$, respectively.

The obtained values of mean total digestibility coefficients of amino acids (TDCAA) for corn and wheat bran (Table 5) were lower than the results of Ribeiro et al. (2011) for corn (89.60\%) and for wheat bran (89.14\%), working with Nile tilapia during the growth phase.

The TDCAA value determined for soybean meal, corn gluten and fish meal (Table 5) were lower than those found by Yamamoto et al. (1998) in common carp, of $92.20 \%$ for soybean meal and $90.60 \%$ for fish meal, and by Ribeiro et al. (2011), of 93.58\% for soybean meal, 92.50\% for corn gluten and $86.01 \%$ for fish meal.

Mean TDCAA values of the protein feedstuffs obtained in the present study (Table 5) were lower than those determined by Ribeiro et al. (2011) and Yamamoto et al. (1998). On the other hand, Wilson et al. (1981), working with channel catfish and also using dissection for feces collection, 
Table 5 - True digestibility coefficients of protein and amino acids in the evaluated feedstuffs as determined by the technique of dissection ${ }^{1}$

\begin{tabular}{|c|c|c|c|c|c|}
\hline & Corn & Wheat bran & Soybean meal & Corn gluten & Fish meal \\
\hline Crude protein & 85.21 & 84.41 & 87.22 & 87.97 & 79.58 \\
\hline \multicolumn{6}{|c|}{ Essential amino acids } \\
\hline Arginine & 88.77 & 86.68 & 91.70 & 92.04 & 84.46 \\
\hline Histidine & 85.10 & 86.92 & 89.40 & 85.04 & 84.50 \\
\hline Isoleucine & 86.35 & 86.95 & 86.06 & 84.99 & 75.29 \\
\hline Leucine & 84.43 & 88.51 & 86.69 & 89.63 & 76.92 \\
\hline Lysine & 86.76 & 80.09 & 87.53 & 89.46 & 72.34 \\
\hline Methionine & 84.60 & 89.25 & 88.31 & 86.27 & 78.81 \\
\hline Phenylalanine & 82.11 & 86.47 & 89.20 & 86.17 & 78.99 \\
\hline Threonine & 81.93 & 81.15 & 89.83 & 87.69 & 81.05 \\
\hline Valine & 83.13 & 83.17 & 86.94 & 87.42 & 77.19 \\
\hline \multicolumn{6}{|c|}{ Non-essential amino acids } \\
\hline Aspartic acid & 82.33 & 81.61 & 88.63 & 89.87 & 69.32 \\
\hline Glutamic acid & 75.97 & 74.08 & 86.28 & 93.26 & 79.30 \\
\hline Alanine & 86.14 & 87.83 & 90.39 & 90.06 & 78.86 \\
\hline Cystine & 80.24 & 78.39 & 82.26 & 82.57 & 84.81 \\
\hline Glycine & 89.68 & 83.05 & 81.15 & 79.64 & 77.12 \\
\hline Serine & 83.42 & 78.27 & 85.73 & 86.57 & 76.86 \\
\hline Tyrosine & 82.49 & 87.39 & 90.07 & 86.74 & 79.17 \\
\hline Mean & 83.97 & 83.74 & 87.51 & 87.34 & 78.44 \\
\hline
\end{tabular}

${ }^{1}$ Values expressed in percentage, on as-fed basis.

obtained lower values, of $84.20 \%$ for soybean meal and $72.50 \%$ for fish meal.

The digestibility coefficient values of the protein fraction of the evaluated feedstuffs were, in general, lower than those reported in the literature, but most studies used the settlement technique for fecal collection (Yamamoto et al., 1998; Furuya et al., 2001; Pezzato et al., 2002; Boscolo et al., 2002; Meurer et al., 2003; Köprücü \& Özdemir, 2005; Gonçalves et al., 2009; Abimorad et al., 2008; Ribeiro et al., 2011). The influence of fecal collection technique was confirmed by some studies that compared the settlement and dissection techniques (Hajen et al., 1993; Storebakken et al., 2000), which causes differences in the determination of digestibility coefficients. These results are consistent with the theory that there is a trend in techniques that use fecal material naturally excreted in the water, such as settlement, to obtain higher digestibility values due to the possible leaching of nutrients in the water (Spyridakis et al., 1989). On the other hand, some authors mention that intact protein can be absorbed in the lower intestine of many fish species (Sire \& Vernier, 1992; McLean et al., 1999), supporting the hypothesis that the material collected by the dissection technique may not have been completed absorbed, thereby resulting in lower digestibility values than those obtained by settlement techniques.

\section{Conclusions}

The apparent digestibility coefficients of protein and amino acids of the tested feedstuffs were 74.69 and $73.62 \%$ for corn, 73.74 and $72.81 \%$ for wheat bran, 86.01 and $84.66 \%$ for soybean meal, 85.19 and $84.29 \%$ for corn gluten and 76.74 and $75.56 \%$ for fish meal, respectively. The true digestibility coefficients of protein and amino acids of the tested feedstuffs were 85.21 and $83.97 \%$ for corn, 84.41 and $83.74 \%$ for wheat bran, 87.22 and $87.51 \%$ for soybean meal, 87.97 and $87.34 \%$ for corn gluten and 79.58 and $78.44 \%$ for fish meal, respectively.

\section{Acknowledgments}

To Ajinomoto Biolatina Indústria e Comércio Ltd., for performing aminograms.

\section{References}

ABIMORAD, E.G.; CARNEIRO, D.J. Métodos de coleta de fezes e determinação dos coeficientes de digestibilidade da fração protéica e da energia dos alimentos para o pacu, Piaracatus mesopotamicus (Holmberg, 1887). Revista Brasileira de Zootecnia, v.33, n.5, p.1101-1109, 2004.

ABIMORAD, E.G.; SQUASSONI, G.H.; CARNEIRO, D.J. Apparent digestility of protein, energy, anda mino acids in some selected feed ingredients for pacu Piaractus mesopotamicus. Aquaculture Nutrition, v.14, p.374-380, 2008.

AKSNES, A.; IZQUIERDO, M.S.; ROBAINA, L. et al. Influence of fish meal quality and feed pellet on growth, feed efficiency and muscle composition in gilthead seabream (Sparus aurata). Aquaculture, v.153, p.251-261, 1997.

AUSTRENG, E. Digestibility determination in fish using chromic oxide marking and analysis of content from different segments of gastro-intestinal tract. Aquaculture, v.13, p.265-272, 1978.

BOSCOLO, W.R.; HAYASHI, C.; MEURER, F. Digestibilidade aparente da energia e nutrientes de alimentos convencionais e 
alternativos para a tilápia do Nilo (Oreochromis niloticus, L.). Revista Brasileira de Zootecnia, v.31, n.2, p.539-545, 2002.

BOSCOLO, W.R.; HAYASHI, C.; MEURER, F. et al. Digestibilidade aparente da energia e proteína das farinhas de resíduos da filetagem da tilápia do Nilo (Oreochromis niloticus) e da corvina (Plagioscion squamosissimus) e farinha integral do camarão canela (Macrobrachium amazonicum) para a tilápia do Nilo. Revista Brasileira de Zootecnia, v.33, n.1, p.8-13, 2004.

CHO, C.Y. Effects of dietary protein and lipid levels on energy metabolism of rainbow trout (Salmo gairdneri). In: EKERN, A.; SUNDSTL, F. (Eds.) Energy metabolism of farm animals. Norway: European Association for Animal Production, 1982. p.175-183.

COSTA, L.F.; LOPES, D.C.; FREITAS, L.S.M. et al. Determinação das perdas endógenas e da digestibilidade ileal da proteína e dos aminoácidos em suínos utilizando-se duas técnicas. Revista Brasileira de Zootecnia, v.37, n.7, p.1243-1250, 2008.

FULLER, M.F. Amino acids requirements for mantenance, body protein accretion and reproduction in pigs. In: D"MELLO, J.P.F. (Ed.). Amino acids in farm animal nutrition. Edinburgh: The Scottish Agricultural College, 1994. p.155-184.

FURUYA, W.N.; PEZZATO, L.E.; PEZZATO, A.C. et al. Coeficientes de digestibilidade e valores de aminoácidos digestíveis de alguns ingredientes para tilápia do Nilo (Oreochromis niloticus). Revista Brasileira de Zootecnia, v.30, n.4, p.1143-1149, 2001.

FURUYA, W.M.; BOTARO, D.; MACEDO, R.M.G et al. Aplicação do conceito de proteína ideal para redução dos níveis de proteína em dietas para tilápia-do-nilo (Oreochromis niloticus). Revista Brasileira de Zootecnia, v.34, n.5, p.1433-1441, 2005.

GLENCROSS, B.D.; BOOTH, M.; ALLAN, G.L. A feed is only as good as its ingredients - a review of ingredient evaluation strategies for aquaculture feeds. Aquaculture Nutrition, v.13, p.17-34, 2007.

GONÇALVES, G.S.; PEZZATO, L.E.; BARROS, M. M. et al. Energia e nutrientes digestíveis de alimentos para a tilápia do Nilo. Boletim do Instituto de Pesca, v.35, n.2, p.201-213, 2009.

HAJEN, W.E.; BEAMES, R.M.; HIGGS, D.A. et al. Digestibility of various feedstuffs by post-juvenile chinook salmon (Oncorhynchus tshawytscha) in sea water. 1. Validation of technique. Aquaculture, v.112, p.321-332, 1993.

HENKEN, A.M.; KLEIGELD, D.W.; TILSSEN, P.A.T. The effect of feeding level on apparent digestibility of dietary dry matter, crude protein and gross energy in the African catfish, Clarias gariepinus, Aquaculture, v.51, p.1-12, 1985.

KÖPRÜCÜ, K.; ÖZDEMIR, Y. Apparent di-gestibility of selected feed ingredients for Nile tilapia (Oreochromis niloticus). Aquaculture, v.250, p.308-316, 2005.

LANNA, E.A.T.; QUADROS, M.; BOMFIM, M.A.D. et al. Freqüência de alimentação em alevinos de tilápia do Nilo (Oreochromis niloticus) utilizando dietas de baixo teor protéico suplementadas com aminoácidos - resultados preliminares. In: REUNIÃO ANUAL DA SOCIEDADE BRASILEIRA DE ZOOTECNIA, 42., 2005, Goiânia. Anais... Goiânia, 2005. (CD-ROM).

MCLEAN, E.; ROENSHOLDT, B.; STEN, C. et al. Gastrointestinal delivery of peptide and protein drugs to aquacultured teleosts. Aquaculture, v.177, p.231-247, 1999.

MEURER, F.; HAYASHI,C.; BOSCOLO, W.R. Fibra Bruta para Alevinos de Tilápia do Nilo (Oreochromis niloticus, L). Revista Brasileira de Zootecnia, v.32, n.2, p.256-261, 2003.
NISSEN, S. Modern methods in protein nutrition and metabolism. New York: Academic Press, 1992. 345p.

PEZZATO, L.E.; MIRANDA, E.D.; BARROS, M.M. et al. Digestibilidade aparente de ingredientes pela tilápia do Nilo (Oreochromis niloticus). Revista Brasileira de Zootecnia, v.31, n.4, p.1595-1604, 2002.

POPMA, T.J.; PHELPS, R.P. Status report to commercial tilápia producers on monosex fingerling productions techniques. In: SIMPÓSIO SUL AMERICANO DE AQUICULTURA, 1., 1998, Recife. Anais... Florianópolis: SIMBRAQ, 1998. p.127.

PORTZ, L. Recentes avanços na determinação das exigências e digestibilidade da proteína e aminoácidos em peixes. In: REUNIÃO DA SOCIEDADE BRASILEIRA DE ZOOTECNIA, 38., 2001, Piracicaba. Anais... Piracicaba, 2001. (CD-ROM).

POZZA, P.C.; GOMES, P.C.; ROSTAGNO, H.S. et al. Avaliação da perda endógena de aminoácido; em função de diferentes níveis de fibra para suíno. Revista Brasileira de Zootecnia, v.32, n.6, p.1354-1361, 2003.

RIBEIRO, F.B.; LANNA, E.A.T.; BOMFIM, M.A.D. et al. Protein and amino acids apparent and true digestibility of feed to Nile tilapia. Revista Brasileira de Zootecnia, v.40, n.5, p.939-946, 2011.

ROMERO, J.J.; CASTRO, E.; DÍAZ, A.M. et al. Evaluation of methods to certify the "premium" quality of Chilean fish meals. Aquaculture, v.124, n.1-4, p.351-358, 1994.

ROSTAGNO, H.S.; FEATHERSTON, W.R. Estudos de métodos para determinação de disponibilidade de aminoácidos. Revista Brasileira de Zootecnia, v.6, n.1, p.64-75, 1977.

SILVA, D.J.; QUEIROZ, A.C. Análise de alimentos: métodos químicos e biológicos. 3.ed. Viçosa, MG: Editora UFV, 2002. $235 p$.

SIRE, M.F.; VERNIER, J.M. Intestinal absorption of protein in teleost fish. Comparative Biochemistry and Physiology Part A: Physiology, v.103, n.4, p.771-781, 1992.

SPYRIDAKIS, P.; METAILLER, R.; GABAUDAN, J. et al. Studies on nutrient digestibility in European sea bass (Dicentrarchus labrax). 1. Methodological aspects concerning faeces collection. Aquaculture, v.77, p.61-70, 1989.

STOREBAKKEN, T.; SHEARER, K.D.; ROEM, A.J. Growth, uptake and retention of nitrogen and phosphorus, and absorption of other minerals in Atlantic salmon Salmo salar fed diets with fish meal and soy-protein concentrate as the main sources of protein. Aquaculture Nutrition, v.6, p.103-108, 2000.

SUGIURA, S.H.; GABAUDAN, J.; DONG, F.M. et al. Dietary microbial phytase supplementation and utilization of phosphorus, trace minerals and protein by rainbow trout Oncorhynchus mykiss (Walbaum) fed soybean meal-based diets. Aquaculture Research, v.32, p.583-592, 2001.

VANDENBERG, G.W.; DE LA NOUE, J. Apparent digestibility comparison in rainbow trout (Oncorhynchus mykiss) assessed using three methods of faeces collection and three digestibility markers. Aquaculture Nutrition, v.7, p.237-245. 2001

YAMAMOTO, T.; AKIMOTO, A.; KISHI, S. et al. Apparent and true availabilities of amino acids from several protein sources for fingerling Rainbow Trout, Common Carp, and Red Sea Bream. Fisheries Science, v.64, n.3, p.448-458, 1998.

WILSON, R.P.; ROBINSON, E.H.; POE, W.E. Apparent and true avilability of amino acids from commom feed ingredients for channel catfish. Journal Nutrition, v.111, p.923-929, 1981.

WINDELL, J.R.; FOLITZ, J.W.; SAROKON, J.P. Methods of fecal collection and nutrient leaching in digestibility studies. The Progressive Fish Culturist, v.40, p.51-55, 1978. 